\title{
Contact-based interventions to reduce ethnic prejudice against migrants and ethnic minorities in the school context: A systematic literature review
}

Ana Lampret

Faculty of Arts, University of Maribor, Slovenia

\section{Abstract}

Positive intergroup contact with peers at school is a crucial factor in the successful integration of migrant and ethnic minority children and adolescents into the local community. Yet, in most cases it is seldom achievable due to prejudice expressed towards ethnic outgroups, which constitutes an important risk factor for social isolation, academic failure, emotional distress, and behavioural problems of children with a migrant or refugee background. Interventions involving intergroup contact have been proven to be the most effective among prejudice-reducing interventions. This article provides a review of the literature on contact-based interventions aimed at reducing ethnic prejudice against migrants, refugees and ethnic minorities in primary and secondary schools. It describes different types of intergroup contact-based interventions - direct, extended, vicarious and imagined - and provides the newest findings on their efficacy. Results are provided for the general factors that influence the effectiveness of interventions for reducing ethnic prejudice in the school context: the age of participants, their ethnic status, the administrator of interventions, the length of interventions, the number of interventions and type of outcome (affective, cognitive, behavioural). At the end, practical implications for performing a successful intervention to lower ethnic prejudice using direct or indirect contact in primary and secondary schools are provided.

Keywords: prejudice reduction, children and adolescents, ethnic prejudice, intergroup contact, systematic literature review 
Sistematični teoretični pregled intervencij za zmanjševanje etničnih predsodkov do migrantov in etničnih manjšin, zasnovanih na medskupinskem kontaktu, v šolskem kontekstu

Povzetek

Pomemben dejavnik uspešnosti integracije vse številčnejših otrok migrantov in pripadnikov etničnih manjšin $\mathrm{v}$ obstoječo skupnost predstavljajo pozitivni medskupinski odnosi v šoli, ki pa so pogosto oteženi zaradi predsodkov do tujih etničnih skupin s strani otrok iz lokalne skupnosti. Predsodki s strani lokalnega okolja za otroke begunce in migrante predstavljajo pomemben dejavnik tveganja za socialno izolacijo, učno neuspešnost, čustvene stiske in vedenjske težave. Intervencije, zasnovane na medskupinskem kontaktu, so se pokazale kot najbolj učinkovite med intervencijami za zmanjševanje etničnih predsodkov. Pričujoč članek obsega pregled študij, ki so izvedle intervencije, zasnovane na medskupinskem kontaktu, z namenom zmanjševanja predsodkov do beguncev, migrantov in etničnih manjšin v osnovnih in srednjih šolah. Povzema izsledke o učinkovitosti posameznih različic medskupinskega kontakta (neposrednega, razširjenega, posrednega in namišljenega) ter najnovejša odkritja glede splošnih dejavnikov, ki vplivajo na učinkovitost intervencij v šolskem kontekstu, kot so starost udeležencev, njihova etnična pripadnost, izvajalec intervencije, dolžina intervencij, število intervencij ter vrsta merjenih izidov (afektivni, kognitivni in vedenjski). Na koncu so navedeni praktični napotki za izvedbo uspešne intervencije $z$ namenom zmanjševanja etničnih predsodkov s pomočjo neposrednega in posrednega kontakta $\mathrm{v}$ osnovnih in srednjih šolah.

Ključne besede: zmanjševanje predsodkov, otroci in mladostniki, etnični predsodki, medskupinski kontakt, sistematični teoretični pregled

\section{Introduction}

The ongoing armed conflicts in Syria, Afghanistan and Iraq of recent years have prompted mass migrations to countries with an ethnically homogenous population in Europe and elsewhere. Between 2013 and 2017, the number of migrants in OECD countries tripled from 2 to 5.9 million (UNHCR,2018), with up to $23 \%$ of the 1.2 million asylum-seekers in 2016 being aged less than 13 years (Eurostat, 2017). These children attend school in their host country as part of the integration process in the hope of learning the local language, adapting to the new culture, and developing a relationship with the local community. 
Supportive intergroup relations are a crucial factor in the successful integration of migrant and ethnic minority children and adolescents into the local community, which is often negatively impacted by prejudice against ethnic majority children (Correa-Velez et al., 2015). Exposure to ethnic prejudice creates an important risk factor for various societal, emotional, behavioural and academic outcomes for the victim. It has been linked to externalising behaviour, such as physical violence and promiscuity, and internalising behaviour like suicidal tendencies (Tobler et al., 2013), depression and anxiety (Benner \& Graham, 2013). It can also lead to hazardous behaviour like substance abuse, which is primarily used as a coping mechanism to reduce emotional distress (Gibbons et al., 2010). This can be said for ethnic minorities in general, as they are commonly subjected to discrimination, which puts them at risk of marginalisation by the majority community (Dustmann \& Preston, 2001). The victims of ethnic prejudice are often socially isolated and bullied, either physically or verbally (Brenick et al., 2019) and are also more prone to lower academic performance, perpetual truancy, and termination of their education (Benner \& Kim, 2009). Migrants and refugees are already at risk for academic failure since only $23 \%$ enter secondary school compared with $84 \%$ of all young people (UNHCR, 2018), which is largely due to not achieving the learning standards of the host country, leading to less classroom participation (Dryden-Peterson, 2015). Research shows that when negative implicit beliefs about ethnic minority members as being less intelligent and capable are held and expressed by teachers and other students this can promote learned helplessness and reduce the motivation to learn among ethnic minority students (Steele \& Aronson, 1995). Ethnic minority students tend to perform significantly below their native peers, with this difference being the most pronounced in highly developed European countries like the Netherlands, Germany and France (Brind et al., 2008). They are more likely to be absent from school, more likely to be expelled, not finish high school and are less likely to continue with their education (Richardson, 2018).

Relationships with ethnic majority classmates are vitally important because as they can worsen the already vulnerable position of migrants and ethnic minorities in the school system, adding to previously present ethnic discrimination in education, or can help to provide a safe learning environment that helps them cope with the host country's learning standards and to develop their academic potential. 


\section{Contact-based interventions aimed at reducing ethnic prejudice}

The negative consequences of ethnic prejudice for the victims and consequently for society have prompted scientists to research ways of reducing negative attitudes to ethnic outgroups. Findings have led to empirically informed interventions. The most widely effective of these are contact-based interventions (Pettigrew \& Tropp, 2006), which are based on the hypothesis that contact between members of different ethnic groups can, in certain conditions, reduce ethnic prejudice against the outgroup and lead to positive intergroup relations (Allport in Brown \& Hewstone, 2005).

In general, school seems quite a perfect place to start tackling prejudice since the large majority of interventions in this context have been effective, irrespective of their theoretical background (Ülger et al., 2018). Contact-based interventions tend to be particularly effective in schools given that the conditions for effective prejudice-reducing intergroup contact can easily be fulfilled. These conditions are: a) equal social status of both groups; b) a uniform goal; c) interdependence among the groups; and d) expressed support from authorities/the institution (ibid.). Students share the status of a class member, while the interaction among them is often facilitated by the teacher or the institution. Tasks that demand cooperation among different groups to achieve a common goal are a frequent way of learning in primary and secondary schools, meaning they can easily be implemented as interventions and have been very successful at reducing prejudice against outgroups (Paluck \& Green, 2009).

Despite their effectiveness, direct contact-based interventions are not commonly implemented in school settings (ibid.) as their implementation can cause significant logistical problems, especially in the case of ethnic segregation or an imbalance in the number of ethnic outgroup members. Gathering enough ethnic minority students can be time-consuming and impractical. Moreover, prejudice should be addressed before direct intergroup contact occurs since even a brief exposure to stigmatisation can bring significant negative outcomes for the victim (Brenick et al., 2019).

For this reason, research has started to focus more on interventions, using indirect intergroup contact (i.e. contact that does not require the physical presence of members from one of the groups), proposing that merely observing or knowing about intergroup contact is enough for prejudice reduction (Wright et al., 1997). Three different approaches have developed from the initial idea, presenting a viable alternative to direct contact: vicarious, extended and imagined intergroup contact. Vicarious intergroup 
contact supposes that observing positive intergroup relations among members of the ingroup and outgroup leads to an improved attitude towards the outgroup. It has mostly been implemented as story-reading about friendships among the members of different ethnic groups (e.g. Cocco et al., 2021). Extended intergroup contact assumes that mere information about an ingroup member's close relationship with an outgroup member can lead to an improved attitude towards the outgroup, which has similarly been implemented as story-reading, although the story mainly focused on the relatable ingroup character having a close friendship with a member of the stigmatised group (e.g. Cameron \& Rutland, 2006). Imagined intergroup contact is the newest empirically proven type of contact-based intervention (Miles \& Crisp, 2013) and proposes that mere thinking about positive intergroup contact leads to an improved attitude towards the outgroup. In the school context, imagined contact has mostly been implemented as researcher-administered visualisation exercises (e.g. Cameron et al., 2011).

In recent years, scientists have started researching new ways to tackle ethnic prejudice given that ethnic diversity in school classes is ever growing due to mass migration and the civil wars in the Middle East. The focus had shifted from reducing prejudice against African and Latino Americans in the USA (Brewer, 1999) to tackling the stigmatisation of migrants and refugees moving from the Middle East to ethnically homogenous countries in Europe and elsewhere around the world. The context of reducing prejudice against migrants is different, as ethnic majority children typically have no former experience with this ethnic group. This also applies to ethnic minorities in countries with a high level of segregation, such as Israel where Palestinians and Israeli Jews live in highly homogenous and ethnically segregated areas, thus leaving them without many opportunities for intergroup contact (Falah, 1996). This issue is especially pressing for migrant and refugee youth as they are an especially vulnerable group, having no knowledge of the language and cultural features of the host country. Therefore, a review of the current literature, focusing on preventing prejudice against migrants, refugees, and ethnic minorities living in highly segregated areas, is in order.

Past reviews mostly focused on direct contact-based interventions to reduce prejudice in general (Pettigrew \& Tropp, 2006), interventions to reduce ethnic prejudice of children below 8 years of age (Aboud et al., 2012), interventions to reduce the prejudice of children and adolescents (Beelmann 
\& Heinemann, 2014) and interventions to reduce prejudice in children and adolescents in educational contexts (Ülger et al., 2018).

In contrast, the present study focuses narrowly on contact-based interventions aimed at reducing ethnic prejudice against refugees, individuals with a migratory background and other ethnic minorities in primary and secondary school. The review only encompasses contact-based interventions since they were initially meant to tackle ethnic prejudice and have been shown to be the most effective in a variety of different settings (Pettigrew \& Tropp, 2006), while also concentrating on implementation in school contexts because this is the primary source of intergroup contact for children and adolescents (Ülger et al., 2018).

According to the aim of the present literature review, we explored the following questions:

1. Are contact-based interventions effective in reducing prejudice against refugees, individuals with a migratory background, and other ethnic minorities in the school context?

2. Do contact-based interventions vary in their effectiveness in reducing ethnic prejudice, depending on the type of intergroup contact?

3. Which characteristics of the contact-based interventions add to their effectiveness in reducing ethnic prejudice in the school context?

4. On which aspects of ethnic prejudice do contact-based interventions have the greatest effect? Does the effect depend on the type of intergroup contact?

\section{Method}

\section{Search strategy}

The search strategy consisted of identifying relevant articles in the multidisciplinary databases Scopus, Web Of Science and Google Scholar, as conducted on 15.6.2020. Search terms were partly based on the PICOS inclusion criteria (Richardson et al., 1995). Articles had to be related to ethnic prejudice (prejudice, discrimination, xenophobia, "ethnic prejudice”, bias, attitude) or prejudice against ethnic minorities (migrants, immigrants, refugees, "ethnic minority"), they had to be based on intergroup contact (contact, "intergroup contact", "vicarious contact", "imagined contact", 
"extended contact") and were implemented in the school context (school, pupils, students, teenagers, adolescent ${ }^{*}$, child $^{*}$ " "primary education", "secondary education", "high school"). We used Boolean operators to combine and limit our search.

Searches were conducted based on title words, keywords and the abstract. The flow diagram below shows the literature search process (Fig. 1). First, we entered our search terms and limited our search by adjusting parameters to only include empirical studies written in the English language. We then merged the three databases and excluded duplicates. Article eligibility was assessed by the researcher, first based on the title, then on the abstract, according to the inclusion criteria. The collecting and reporting of results was done according to the PRISMA guidelines (Moher et al., 2009).

\section{Inclusion criteria}

Interventions had to meet the following criteria to be included in the study:

1. The research was written in English.

2. Sufficient data were provided to enable effect-size calculations.

The PICOS inclusion criteria:

3. Population: The target group was young people attending primary and secondary school, aged between $6-18$ years.

4. Intervention: The study included a standardised contact-based intervention (i.e. direct, extended, vicarious, imagined) aimed at lowering ethnic prejudice against refugees and individuals with a migratory background, implemented in the school context.

5. Comparison: The intervention involved a comparison of a control and an experimental group.

6. Outcome: Cognitive, affective and behavioural aspects of ethnic prejudice were measured.

7. Study: The research had an experimental design.

\section{Coding procedure}

Suitable articles were subjected to a recording procedure. Relevant information about each intervention was recorded: the country of implementation, type of intervention, ethnic status of the target group, age of participants, administrator of the intervention, number of sessions, duration 

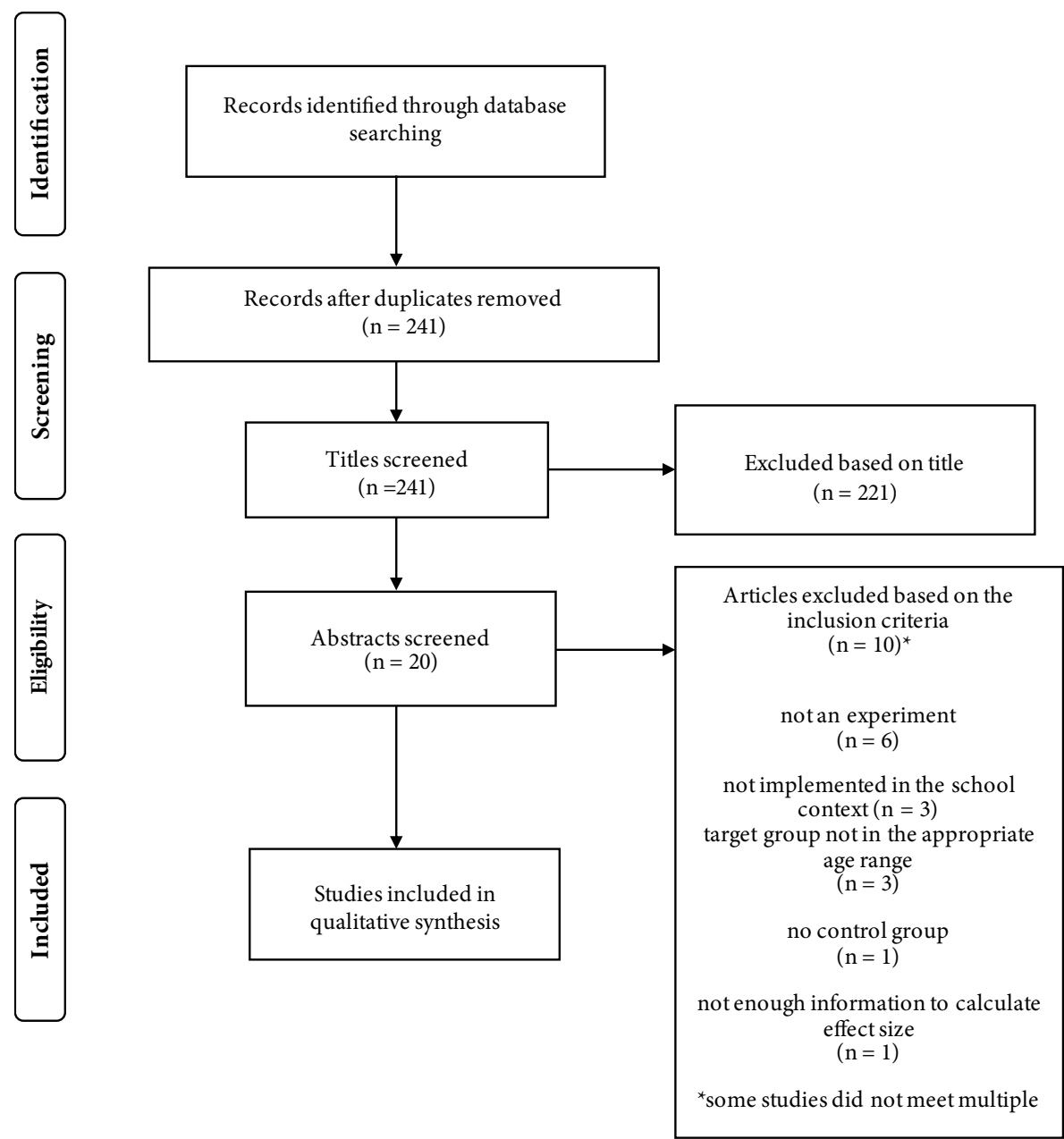

\section{Figure 1. Flow diagram for the inclusion/exclusion of studies.}

of the intervention and outcomes of the intervention. Ethnic status of the target group was coded as ethnic majority and mixed if some participants were of the ethnic majority and some of the ethnic minority. No intervention solely included members of an ethnic minority and thus we excluded the category. Studies were also coded based on the participants' age. For studies involving participants from multiple age categories, mean age was taken as a defining parameter. We categorised outcomes in three categories based on prejudice components (Beelmann \& Heinemann, 2014): cognitive (i.e. expectations of outgroup members), affective (i.e. a negative affect 
that accompanies cognitive appraisal) and behavioural (i.e. negative behaviour towards members of the outgroup) (Brown in Brenick, et al., 2019). Cognitive outcomes included stereotypes and attitudes towards the outgroup, perceived similarity with the outgroup, and perceived importance of future contact with the outgroup. Affective outcomes included negative emotions, intergroup anxiety, and fear of rejection by members of the outgroup, while behavioural outcomes included intentions of making intergroup contact, intentions to help an outgroup member, readiness for social intergroup contact, propensity to discriminate, and intention to self-disclose to outgroup members. Some studies are included in multiple categories since they include more than one age group, type of intervention, or outcome of intervention. A description of the studies is given in Table 2.

\section{Computation and testing of effect sizes}

For each measured outcome, Cohen's $d$ was provided either from the article or was calculated from the sample size, mean and standard deviation of the control and experimental group with Psychometrica (Lenhard \& Lenhard, 2016). We calculated the mean effect size and $95 \%$ confidence interval for every category recorded. Every reported effect size that fit a certain category was included in the calculation of the mean effect size and $95 \%$ confidence interval. The number of effect sizes $(n)$, mean effect size $(d+)$ and 95\% confidence interval were reported for each researched category. Results were interpreted according to Cohen (in Lenhard \& Lenhard, 2016), with values less than o denoting an adverse effect, o to 0.1 a negligible effect, 0.2 to 0.4 a small effect, 0.5 to 0.7 a moderate effect and 0.8 to 1.0 a large effect. Positive effects $(d>0)$ were regarded as successful intervention implementation and an attitude improvement towards ethnic outgroups, while negative effects of interventions $(d<0)$ were regarded as an ineffective or detrimental effect on prejudice or related outcomes.

\section{Assessment of article quality}

A quality assessment was performed using an adapted version of Joanna Briggs checklist for Randomized Control Trials (Tufanaru et al., 2017). We excluded criteria which required the blindness of intervention administrators (5th criterion), intention to treat analysis (9th criterion) and appropriateness of the RCT design depending on the patients' condition (13th criterion), because they only applied to RCT interventions in medical research. Other criteria were adapted to assess the quality of psychological research. 
We assessed research design according to 10 criteria: randomisation for assignment of the participants to treatment groups, concealed allocation of the participants to conditions, similarity of groups at the baseline, blindness of the participants to group assignment, blindness of the outcome assessors to group assignment, identical treatment of the groups other than intervention, completeness of the follow-up, identical outcome measurement for groups, sufficient reliability of the measures ( $\alpha>0.75$ ) (Bucik, 1997) and the use of appropriate statistical analysis procedures. A point was given for each criterion met, meaning a particular article could achieve a total of 10 points. The assessment of article quality is presented in Table 2.

\section{Results and discussion}

In this section, the combined results of the studies included in the systematic review are presented. The section is divided into multiple subchapters according to the research questions set out written in the introductory part of this paper. First, we provide results concerning the general effectiveness of contact-based interventions and compare the effectiveness of direct and indirect contact interventions. Our focus then shifts to the characteristics of interventions that were shown to be important contributors to their effectiveness. We compare the effectiveness of interventions depending on characteristics of the target group, namely the participants' ethnic status and age. Below, we focus on relevant characteristics of the intervention itself and compare effectiveness as regards the intervention administrator, the duration, and the number of sessions. Finally, we compare the interventions' participants with respect to different types of outcomes.

\section{Effectiveness of contact-based interventions}

According to the results, contact-based interventions had on average a small-to-moderate positive effect on prejudice and related outcomes (see Table 1), which is in line with the average effect sizes in a meta-analytic review by Ülger et al., $2018\left(k^{1}=19, d+=0.46,95 \%\right.$ CI [0.23, 0.68]). All studies reported having at least one significant effect between or within groups over time, while 8 of 10 reported significant effects on most outcomes. Two studies with mostly non-significant results $(n=8, d+=0.05,95 \% \mathrm{CI}$ [0.01, 0.09]) were of lower research quality (see Table 2, namely Liebkind et al., 2013; Vezzali et al., 2018), again proving methodological quality to be 
Table 1: Effectiveness of interventions based on different parameters.

\begin{tabular}{|c|c|c|c|c|}
\hline & & $\mathrm{n}$ & $\mathrm{d}+$ & $95 \% \mathrm{CI}$ \\
\hline Contact-based interventions ${ }^{*}$ & & 42 & 0.48 & $0.37,0.60$ \\
\hline \multicolumn{5}{|c|}{ Types of contact-based interventions } \\
\hline & Direct contact-based interventions & 6 & 0.82 & $0.66,0.99$ \\
\hline & Indirect contact-based interventions & 34 & 0.37 & $0.26,0.48$ \\
\hline \multicolumn{5}{|c|}{$\begin{array}{l}\text { Types of indirect contact-based in- } \\
\text { terventions }\end{array}$} \\
\hline & $\begin{array}{l}\text { Vicarious contact-based interven- } \\
\text { tions }\end{array}$ & 13 & 0.22 & $0.09,0.35$ \\
\hline & $\begin{array}{l}\text { Extended contact-based interven- } \\
\text { tions }\end{array}$ & 13 & 0.31 & $0.16,0.46$ \\
\hline & $\begin{array}{l}\text { Imagined contact-based interven- } \\
\text { tions }\end{array}$ & 8 & 0.72 & $0.50,0.93$ \\
\hline \multicolumn{5}{|l|}{ Ethnic status } \\
\hline & Ethnic majority group members & 24 & 0.43 & $0.32,0.54$ \\
\hline & Mixed ethnic group members & 14 & 0.35 & $0.15,0.55$ \\
\hline \multicolumn{5}{|l|}{ Age of participants } \\
\hline & Less than 9 years & 11 & 0.52 & $0.36,0.68$ \\
\hline & Between 9-11 years & 14 & 0.77 & $0.57,0.98$ \\
\hline & Above 12 years & 8 & 0.05 & $0.01,0.09$ \\
\hline \multicolumn{5}{|l|}{ Administrator of intervention } \\
\hline & Teacher & 5 & 0.07 & $0.01,0.13$ \\
\hline & Researcher & 20 & 0.41 & $0.28,0.54$ \\
\hline & External colleague & 4 & 0.76 & $0.57,0.95$ \\
\hline & Student & 5 & 0.19 & $0.00,0.37$ \\
\hline \multicolumn{5}{|l|}{ Number of sessions } \\
\hline & 1 session & 5 & 0.09 & $0.06,0.12$ \\
\hline & 3 sessions & 17 & 0.66 & $0.45,0.87$ \\
\hline & 6 sessions & 13 & 0.31 & $0.27,0.35$ \\
\hline & 12 sessions & 4 & 0.76 & $0.56,0.95$ \\
\hline \multicolumn{5}{|l|}{ Length of sessions } \\
\hline & Less than $20 \mathrm{~min}$ & 12 & 0.3 & $0.15,0.46$ \\
\hline & 20 to $60 \mathrm{~min}$ & 12 & 0.76 & $0.48,1.04$ \\
\hline & 2 to 4 hours & 6 & 0.65 & $0.46,0.85$ \\
\hline \multicolumn{5}{|c|}{ Direct contact intervention outcomes } \\
\hline & Cognitive & 2 & 0.93 & $0.83,1.02$ \\
\hline & Affective & 1 & 0.78 & 1 \\
\hline & Behavioural & 3 & 0.77 & $0.43,1.10$ \\
\hline \multicolumn{5}{|l|}{$\begin{array}{l}\text { Indirect contact intervention ou- } \\
\text { tcomes }\end{array}$} \\
\hline & Cognitive & 14 & 0.42 & $0.25,0.59$ \\
\hline & Affective & 3 & 0.05 & $0.02,0.08$ \\
\hline & Behavioural & 14 & 0.36 & $0.29,0.43$ \\
\hline
\end{tabular}

Note. $n=$ number of calculated effect sizes. $d+=$ mean effect size. $95 \% \mathrm{Cl}=95 \%$ confidence interval for calculated mean effect size. *Results include all calculated intervention effect sizes. 
significant for an intervention's effectiveness (Aboud et al., 2012; Beelmann \& Heinemann, 2014; Ülger et al., 2018).

\section{Effectiveness of direct and indirect contact-based interventions}

We excluded one condition of the study by Vezzali et al. (2015a) from the analysis as subjects were simultaneously exposed to direct and indirect contact. Most direct intergroup contact conditions reported large effects on prejudice and related outcomes, while indirect intergroup contact conditions generally had small effects (see Table 1). These results are in line with the findings of Christ et al. (2010) that direct contact may have a bigger effect on prejudice reduction as it always leads to indirect contact through the observation of contact between ingroup and outgroup members. Similarly, a field study found that long-term direct contact had a positive effect on attitudes towards minority children, while extended intergroup contact had no long-term effect (Feddes et al., 2009).

Vezzali et al. (2015a) explicitly compared intervention effectiveness based on the directness of contact in which they compared the effectiveness of direct and imagined contact conditions. Imagined intergroup contact condition had a slightly bigger effect on cognitive and slightly smaller effect on behavioural outcomes than the direct contact condition, although the differences were not significant. The results show that imagined contact has similar effects on prejudice and related outcomes as direct contact while, when applied simultaneously, both types of contact have an additive effect.

The findings of other studies show that indirect contact interventions could have comparable effects, but might be more prone to ineffectiveness if the quality of the administration is low and optimal conditions are not provided, especially in the case of extended and vicarious contact (see paragraph 3.1.2 below). This difference in effect could also be due to not having a representative sample for direct contact interventions since the two studies that investigated the effects of direct contact interventions were of very high methodological and general administration quality, which could contribute significantly to their effectiveness (Ülger et al., 2018). It might also be possible that direct contact is instantly effective while indirect contact effects are apparent only after some time has passed (Christ et al., 2010). Since the follow-up was done after a relatively short time (for most studies after 3 weeks), indirect contact interventions may seem to have less effect than direct contact interventions. 


\section{Effectiveness of different indirect contact interventions}

Analysis of effectiveness for different indirect contact conditions shows extended intergroup contact having small-to-moderate effects, imagined intergroup contact having moderate-to-large effects, and vicarious intergroup contact mainly having negligible-to-small effects (see Table 1).

The results show that imagined and extended contact can both be highly efficacious if research is high in methodological quality and implements other factors supposedly connected to effective implementation (e.g. the age appropriateness of the intervention) (Ülger et al., 2018). The imagined contact interventions included in this review are high in quality, while the extended contact interventions' quality varies, which could contribute to such differences. A meta-analysis of 70 studies measuring imagined contact intervention effects reported a small effect on prejudice and related outcomes $(d+=0.35)$ (Miles \& Crisp, 2013), suggesting our sample of interventions was particularly efficacious. Nothing could be deduced about vicarious contact interventions as this was implemented by only two studies of low methodological quality, which might add to its ineffectiveness (Aboud et al., 2012; Beelmann \& Heinemann, 2014; Ülger et al., 2018).

Another possible explanation is that extended and vicarious contact interventions are simply more prone to being ineffective if certain conditions are not met, such as perceived prototypicality of ingroup and outgroup peer models or group salience (Brown \& Hewstone, 2005). Accordingly, the results of Liebkind et al. (2013) show that vicarious contact intervention effectiveness is related to the perceived group prototypicality of characters from the story. Imagined contact may be more efficacious as participants are naturally exposed to their own prototypical representations of outgroup members during visualisation, meaning that this condition is automatically met.

\section{Factors influencing the effectiveness of contact-based interventions}

\section{Characteristics of the target group: ethnic status}

None of the interventions focused solely on ethnic minority students, which led us to compare interventions with only ethnic majority participants against interventions with participants of ethnic minority and majority group memberships. Interventions with members of the ethnic majority reported small-to-moderate effects, while interventions with ethnically-mixed participants reported small effects (see Table 1.). This is in line with Ülger et al. (2018) who reported similar effect sizes for participants 
of ethnic majority $\left(k^{2}=40, d+=0.40,95 \% \mathrm{CI}[0.17,0.64]\right)$ and minority $\left(k^{2}=\right.$ $7, d+=0.23,95 \%$ CI $[-0.06,0.52])$ groups.

Three studies included ethnic minorities. The sample of Berger et al. (2016) was comprised of $50 \%$ ethnic minority students native to their country of residence. Intervention effectiveness did not differ significantly depending on the participants' ethnic status, although a slightly bigger reduction of the propensity to discriminate for ethnic majority students was reported compared to ethnic minority students right after the intervention. Recently migrated participants or participants with a migratory background comprised approximately $26 \%$ of the sample in Liebkind et al. (2013) and Vezzali et al. (2018). Both found ethnic status to be unrelated to intervention effectiveness.

Contact-based interventions can be effective regardless of the participants' ethnic status, yet the results show a slightly bigger effect of interventions on ethnic majority students. This difference may be explained by ethnic minority children already having favourable attitudes towards ethnic majority members. Yet this proposed explanation cannot be applied to the results of an intervention executed in an Israeli-Palestinian context (i.e. Berger et al., 2016) because studies have shown that Palestinians, an ethnic minority, hold similar negative beliefs towards ethnic majority members, Israeli Jews, as they have toward them (Bar-Tal, 1996; Brenick et al., 2010).

Another explanation of the general results may be that this effect is due to most interventions' primary focus on altering the prejudice of ethnic majority children (Aboud et al., 2012). In most studies, prejudice expressed by ethnic majority members towards stigmatised ethnic groups was the primary target of the intervention, as reflected in the selection of the participants (see Table 1), structure and content of the intervention (e.g. leading discussions on the topics of refugees and explaining their cultural specifics). Subsequently, not much attention was given to measuring and reducing any potential negative beliefs of ethnic minorities towards ethnic majority members. Again, this cannot be said for the intervention described by Berger et al. (2016) since prejudice on both sides was addressed equally and both groups were treated as equals (e.g. speaking in the native languages of both communities). Still, nothing of substance can be said since the sample size for mixed ethnic group participants was too small, even though most studies found that ethnic status is not a significant predictor of intervention effectiveness. 
Characteristics of the target group: cognitive development and age We excluded the Cameron et al. (2006) study from our analysis of effect sizes because not enough information was provided to calculate the effect sizes for different age groups. The results show that the interventions have small-to-moderate effects on children under 9 years of age, on participants aged 9-11 years moderate-to-large effects and on participants over 12 years negligible effects (see Table 1).

Interventions seem to have been the most effective when they involved children aged 9 to 11 . The biggest effects were obtained for 8- to 10-year-olds (Berger et al., 2016; Vezzali et al. 2015a), which is in line with findings from developmental psychology that show children in the transition from middle to late childhood are particularly susceptible to their social environment. This developmental period may represent a crucial point in the development of prejudice as negative attitudes significantly increase/decrease depending on intergroup contact opportunities (Raabe \& Beelmann, 2011).

Two of the studies included in the systematic analysis specifically measured differences in intervention effectiveness based on the participants' age. Cameron et al. (2006) found younger children (5- to 8-yearolds) hold significantly more positive attitudes and behavioural intentions towards the outgroup than the older children (9- to 11-year-olds). However, attitudes were only measured after the children had received the intervention, so it may be a case of younger children initially having more positive attitudes towards migrants than an age-related difference in intervention effectiveness.

Cameron et al. (2007) also found that younger children (6- to 8-yearsold) have more positive behavioural intentions than older children (9- to 11-years-old), albeit the effects were not significant. The intervention had a similar effect on behavioural outcomes for older and younger children. The effect of multiple classification skills on prejudicial attitudes was also tested that might contribute to prejudice reduction among older children. Theory proposes that multiple classification enables children to perceive individual characteristics of ethnic outgroup members and their similarities with the ethnic ingroup and increases their capacity to remember information inconsistent with their expectations, such as positive experiences with stigmatised group members (Aboud et al., 2012). Still, the study found no effect of multiple classification skills training on prejudicial attitudes, suggesting that prejudice reduction may be independent of cognitive development in 
children. This indicates that contact-based interventions may be effective for both age groups.

Interventions seem mostly to have had no effect on teenagers, perhaps because of an unrepresentative sample, lower research quality and the lack of optimal conditions for effective intervention execution (i.e. an intervention administered by untrained teachers and students, non-standardised research conditions) (Ülger et al., 2018) or it could be attributed to the participants' age. Prejudice might be less malleable in adolescence (Augoustinos \& Rosewarne, 2001), making prejudice-reducing interventions less effective. Yet, other findings indicate successful contact-based interventions can be administered to an adolescent population (e.g. Tropp \& Ramiah, 2017).

\section{Characteristics of intervention implementation: administrator of the intervention}

We excluded Vezzali et al. (2015a) from this analysis since who administered the intervention is not specified. When the administrator was a teacher, the intervention produced negligible effects, while interventions administered by researchers as the administrator produced small-to-moderate effects. Interventions produced moderate-to-large effects when administered by external colleagues and negligible-to-small effects when administered by students (see Table 1).

Teachers conducted an intervention in only one study (Vezzali et al., 2018) that produced no effect on outcome measures, which is consistent with several metanalyses that found no effect for teacher-administered interventions (Aboud et al., 2012; Ülger et al., 2018). Such results may be attributed to the lack of sufficient training for intervention execution because it was not specified if the teachers had even received training or perhaps standardisation was lacking since teachers sometimes do not perceive it to be of primary importance or cannot follow the exact procedure due to time restrictions (Stains \& Vickrey, 2017). Still, not much can be speculated given that only one study of this kind was included in the review.

Similar effects were observed for interventions administered by students, who had purportedly received training in both studies (Liebkind et al., 2013; Vezzali et al., 2015b), although this is not explained in detail.

When researchers conducted the intervention, no specific trend was observed since the effects varied in size. Administrators have been the authors of the study (Cameron et al., 2006, 2007), assistants to the study's 
authors (Vezzali et al., 2011) or were not explicitly defined (Stathi et al., 2014; Vezzali et al., 2014). Interventions administered by researchers might be more effective because of the greater standardisation procedure and expertise, but also since they represent a novelty in the classroom and remind participants of their participation in the experiment, which could induce socially desirable behaviour and perhaps even lead to inflated intervention effects (Kintz et al., 1965).

Interventions were the most effective when carried out by experienced and trained external administrators (i.e. Berger et al., 2016). Administrators were chosen based on their experience of leading interethnic groups and received 2 days of training on prejudice formation and contact theory prior to the intervention starting.

Interventions were the least effective when the training was not specified or only briefly mentioned (Liebkind et al., 2013; Vezzali et al., 2015b; Vezzali et al., 2018), which allows us to assume it was less structured and unsystematic.

\section{Characteristics of intervention implementation: duration and number of sessions}

The results show that on average interventions entailing 12 sessions produced moderate-to-large effects, those with 6 sessions small effects, those with 3 sessions moderate-to-large effects and finally those with just 1 session negligible effects (see Table 1).

Interventions were the most effective when the number of sessions was greater, although the results also show that a smaller number of interventions can have similar effects (e.g. Vezzali et al., 2011, 2015a). Effective prejudice-reducing interventions must be well integrated into the school culture to ensure that students are perpetually exposed to diversity acceptance norm (Cotton in Ülger et al., 2018). Accordingly, contact-based interventions with more sessions are shown to be more effective as they demand the school's stronger commitment to reducing prejudice (Beelmann \& Heinemann, 2014).

While comparing the session lengths, we excluded the studies by Stathi et al. (2014), Vezzali et al. (2014) and Vezzali et al. (2018) because they did not provide such information. On average, interventions with sessions of 2 to 4 hours produced moderate-to-large effects, interventions with sessions of 20 to $60 \mathrm{~min}$ produced moderate-to-large effects, and interventions with sessions of less than 20 min small effects (see Table 1). The smallest 
effects were reported for interventions with sessions lasting less than 20 minutes, while sessions of a moderate length produced the largest effects. The relationship between intervention effectiveness and session length may be described as an inverted- $U$ curve whereby interventions of a moderate duration (30-60 min) are the most effective. Shorter sessions may impose serious time constraints on the administrators, forcing them to rush through the whole intervention procedure. Not enough time is then given for adequate instruction, while students may not have sufficient time to properly finish a given task. Longer sessions might not contribute to intervention effectiveness due to the fatigue of participants and intervention administrators, causing them to lack in concentration and motivation.

However, the results cannot be generalised as one study with three 1-hour-long sessions (Vezzali et al., 2015a) recorded many large effects, which outweighed the effect sizes of the other studies in the analysis. If we were to exclude this study, three-session interventions would report predominantly small effects and 30- to 6o-minute interventions would mostly report negligible positive effects. Still, a linear trend can be observed in terms of the number of sessions since the effectiveness of interventions increases with their number.

Interventions seem to be most effective when they have multiple sessions and are moderate in length. This is in line with the findings of Ülger et al. (2018) that longer interventions with multiple sessions effects are statistically significant, while short one-off interventions effects are statistically non-significant. Yet, only one of the latter was included in our review, which makes it impossible to generalise the findings. Negligible effects might also be due to the poorer methodological quality of a study (see Table 1). Nevertheless, our results indicate that frequent and long-term direct or indirect exposure to members of an ethnic outgroup can more effectively reduce prejudice since the likelihood of positive interactions and experiences with members of the outgroup has increased (Brown \& Hewstone, 2005).

\section{Outcomes of contact-based interventions}

Direct contact interventions had moderate-to-large effects on behavioural outcomes (i.e. propensity to discriminate, intention to help an outgroup member), large effects on cognitive outcomes (i.e. negative stereotypes) and a moderate effect on affective outcomes (i.e. negative emotions towards the outgroup) (see Table 1). 
Direct contact produced a smaller effect on a negative affective outcome compared to behavioural and cognitive outcomes, which contradicts the findings of a meta-analysis by Pettigrew and Tropp (2006) that interventions based on direct contact are expected to produce the largest effects on negative affective outcomes. However, only one measurement of a negative affective outcome for direct contact interventions was included in the analysis, and thus we cannot generalise our findings.

Consistent with the results of Paolini et al. (2007), our analysis shows direct contact interventions produce moderate effects on behavioural outcomes even after a longer period of time, as Berger et al. (2016) reported significant positive effects on behavioural outcomes (i.e. number of intergroup friendships) 15 months after the intervention.

Indirect contact-based interventions produced small-to-moderate effects on cognitive outcomes, small effects on behavioural outcomes, and negligible effects on affective outcomes (see Table 1 ). This is consistent with Paolini et al. (2007) who state that indirect contact interventions could have a greater effect on cognitive outcomes than behavioural and affective ones.

Direct contact interventions produced larger effects on all three types of outcomes, which is consistent with Turner et al. (2007). A particularly large difference in effect can be seen for affective outcomes, which may indicate that direct contact is particularly efficacious at reducing affective aspects of prejudice, as reported by Pettigrew and Tropp (2006). Still, these differences cannot be generalised because the number of studies that conducted a direct contact intervention was extremely small.

\section{Limitations and directions for future research}

Several prominent limitations of this review should be addressed. First, we investigated a limited amount of potentially relevant factors that contribute to intervention effectiveness. Intervention effectiveness might also vary depending on the cultural environment and specifics of the intergroup contact (Ülger et al., 2018). Not all interventions included in the present paper can be compared with each other as they were executed in quite different cultural settings, which explains why some of our results may be deemed inconclusive. The study by Berger et al. (2016), for example, stands out from the other studies included as the ethnic minority group (i.e. Palestinians) is native to Israel while the other studies mostly focused on reducing prejudice against recently migrated ethnic minorities. Conducting an intervention in such a setting may require a different approach from the rest 
as prejudice towards the other group might be more ingrained in people's cultural identity and stem from traumatic experiences such as armed confrontations during the Israel-Gaza conflict in 2014 and in May of this year (Bilefsky, 2021).

Second, the qualitative analysis considered a small sample of studies as only 10 prejudice-reducing interventions met the inclusion criteria. If we were to compute only one effect size for each treatment group, we would be unable to calculate the mean effect size and confidence intervals, which meant we had to violate the assumption of independence between effect sizes. Consequently, we could only speculate on the differences in intervention effectiveness. The number of studies included was so small that the one intervention with many significant results might have overshadowed the results of the other interventions. Third, publication bias (i.e. the risk of reporting only statistically significant results) was not evaluated. Since two of the ten studies recorded mostly non-significant results, we estimate that the risk of publication bias in this research area is low. Lastly, there remains the possibility not all suitable studies were included in the review because articles were drawn from just three databases.

The interventions included in this review were conducted almost exclusively in Italy and Great Britain and by the same sets of researchers, which makes it difficult to generalise the findings to all cultural settings. The optimal ways to reduce ethnic prejudice might depend on the cultural environment and specifics of the intergroup contact (Ülger et al., 2018). Thus, future studies could be conducted in other European countries, like for example Germany, that in 2016 recorded the biggest influx of migrants into Europe (Eurostat, 2017) or Turkey, among non-European countries (Canefe, 2016). Only one study that was included (i.e. Berger et al., 2016) explored ways of tackling the prejudice of ethnic minority students. Reducing prejudice among members of ethnic minorities should not be overlooked as that could help increase their motivation to engage in contact and subsequently lead to more frequent intergroup contact (Glasford \& Dovidio, 2011). Further research should also find ways of successfully conducting interventions involving the adolescent population and assessing the longterm effects of indirect contact interventions (Brown \& Hewstone, 2005; Christ et al., 2010).

In the future, studies should also consider more behavioural measures, especially measures of actual behaviour (e.g. intergroup friendship 1 year after the intervention like in Berger et al. (2016)), instead of hypothetical 
behaviour. Just one study (Vezzali et al., 2011) measured implicit attitudes towards an outgroup. Findings show that prejudicial attitudes become more implicit with age (Raabe \& Beelmann, 2011), thus measures of implicit prejudice should be used more often in future studies, especially those with older children and adolescents.

\section{Conclusions and practical implications}

In the present paper, we reviewed ten studies that conducted contact-based interventions to reduce ethnic prejudice against migrants in the school context. Our study is among the first to consider the recent shift in prejudice prevention research that specifically focuses on the current issue of reducing prejudice to facilitate the integration of migrants, refugees and other ethnic minorities into existing communities. This review is also one the first to address differences in effectiveness depending on the type of indirect contact. Given that indirect contact interventions are much less logistically demanding and can be carried out preventively in schools even before migrants are included in the educational process, our findings hold important implications for the widespread implementation of indirect contact interventions in European schools.

The review findings provide valuable suggestions for conducting an effective prejudice-reducing intervention in the school context. The decision on whether to perform a direct or indirect contact-based intervention should be based on opportunities to include members of the ethnic minority and the type of outcomes intended to be achieved. A direct contact intervention is appropriate if migrants and ethnic minority students are already enrolled in an educational institution and there is a need to reduce negative feelings associated with an outgroup (e.g. fear of the outgroup) and to create long-lasting behaviour change (e.g. intergroup friendships, reduction of discrimination). An indirect contact intervention is appropriate when gathering enough ethnic minority students is impossible and there is a need to reduce negative beliefs and stereotypes in ethnic majority children before the initiation of intergroup contact. Extended and vicarious contact should only be implemented in highly controlled and standardised interventions since their effectiveness relies on certain conditions that may prove hard to achieve (e.g. perceived typicality of ethnic group members in a story) (Liebkind et al., 2013). Imagined contact interventions have fewer requirements that are typically easier to fulfil (e.g. variability in imagined scenarios to generalise the effect) (Miles \& Crisp, 2013), which makes them 
the best to implement in practice. Intervention administrators should be given systematic training before the intervention starts and, if possible, be experienced in leading workshops for ethnically diverse groups. As many sessions as feasible should be included while still considering the intervention's time-efficiency. Individual sessions should be long enough so as not to impose time constraints on the administrators and participants, while still short enough to not risk the participants' fatigue and loss of attention. We recommend that sessions last 20-60 min or longer, although participants' age and task complexity must be taken into account.

\section{Funding acknowledgement declaration}

The author received no financial support for the research, authorship or publication of this article.

\section{Appendix}

Table 2: Description of the interventions included in the systematic literature review.

\begin{tabular}{|c|c|c|c|c|c|c|c|c|}
\hline $\begin{array}{c}\text { Authors } \\
\text { (year of publi- } \\
\text { cation) }\end{array}$ & Country & $\mathrm{N}$ & $\begin{array}{l}\text { Interven- } \\
\text { tion }\end{array}$ & Setting & $\begin{array}{c}\text { Sample } \\
\text { characteristics } \\
\text { Age; Ethnic } \\
\text { status* }\end{array}$ & $\begin{array}{l}\text { Interventi- } \\
\text { on implemen- } \\
\text { tation } \\
\text { Administra- } \\
\text { tor; Number } \\
\text { and duration of } \\
\text { sessions }\end{array}$ & $\begin{array}{c}\text { Study } \\
\text { limitations }\end{array}$ & $\begin{array}{c}\text { Research } \\
\text { quality } \\
\text { by Tufanaru et } \\
\text { al. (2017) }\end{array}$ \\
\hline $\begin{array}{l}\text { Berger et al. } \\
(2016)\end{array}$ & Israel & 322 & DC & $\begin{array}{l}\text { Conflict } \\
\text { between two } \\
\text { native ethnic } \\
\text { groups Isra- } \\
\text { eli-Jews ( } 80 \% \\
\text { of the popu- } \\
\text { lation) and } \\
\text { Palestini- } \\
\text { ans ( } 20 \% \text { of } \\
\text { the populati- } \\
\text { on), living in } \\
\text { highly segre- } \\
\text { gated com- } \\
\text { munities in } \\
\text { Jaffa }\end{array}$ & $\begin{array}{l}8-9 \text { years old; } \\
\text { Ethnic majo- } \\
\text { rity and mi- } \\
\text { nority }(50 \%)\end{array}$ & $\begin{array}{l}\text { External co- } \\
\text { lleagues; } 12 \\
\text { sessions ( } 2 \mathrm{x} \\
\text { month); } 4 \\
\text { hours }\end{array}$ & $\begin{array}{l}\text { Parents noti- } \\
\text { fied of resear- } \\
\text { ch aim. }\end{array}$ & 9 \\
\hline $\begin{array}{l}\text { Cameron et } \\
\text { al. }(2007)\end{array}$ & GB & 198 & EC & $\begin{array}{l}\text { Tensions } \\
\text { between the } \\
\text { majority whi- } \\
\text { te British } \\
\text { communi- } \\
\text { ty and ethnic } \\
\text { minority im- } \\
\text { migrants and } \\
\text { refugees }\end{array}$ & $\begin{array}{l}6-8 \text { and } 9-11 \\
\text { years; Ethnic } \\
\text { majority }\end{array}$ & $\begin{array}{l}\text { Researcher; } 6 \\
\text { sessions (1x } \\
\text { week); 15-20 } \\
\text { min }\end{array}$ & $\begin{array}{l}\text { No info. on } \\
\text { age structure } \\
\text { for each con- } \\
\text { dition, parti- } \\
\text { cipants, and } \\
\text { assessors } \\
\text { blindness of } \\
\text { condition } \\
\text { assignment }\end{array}$ & 7 \\
\hline
\end{tabular}




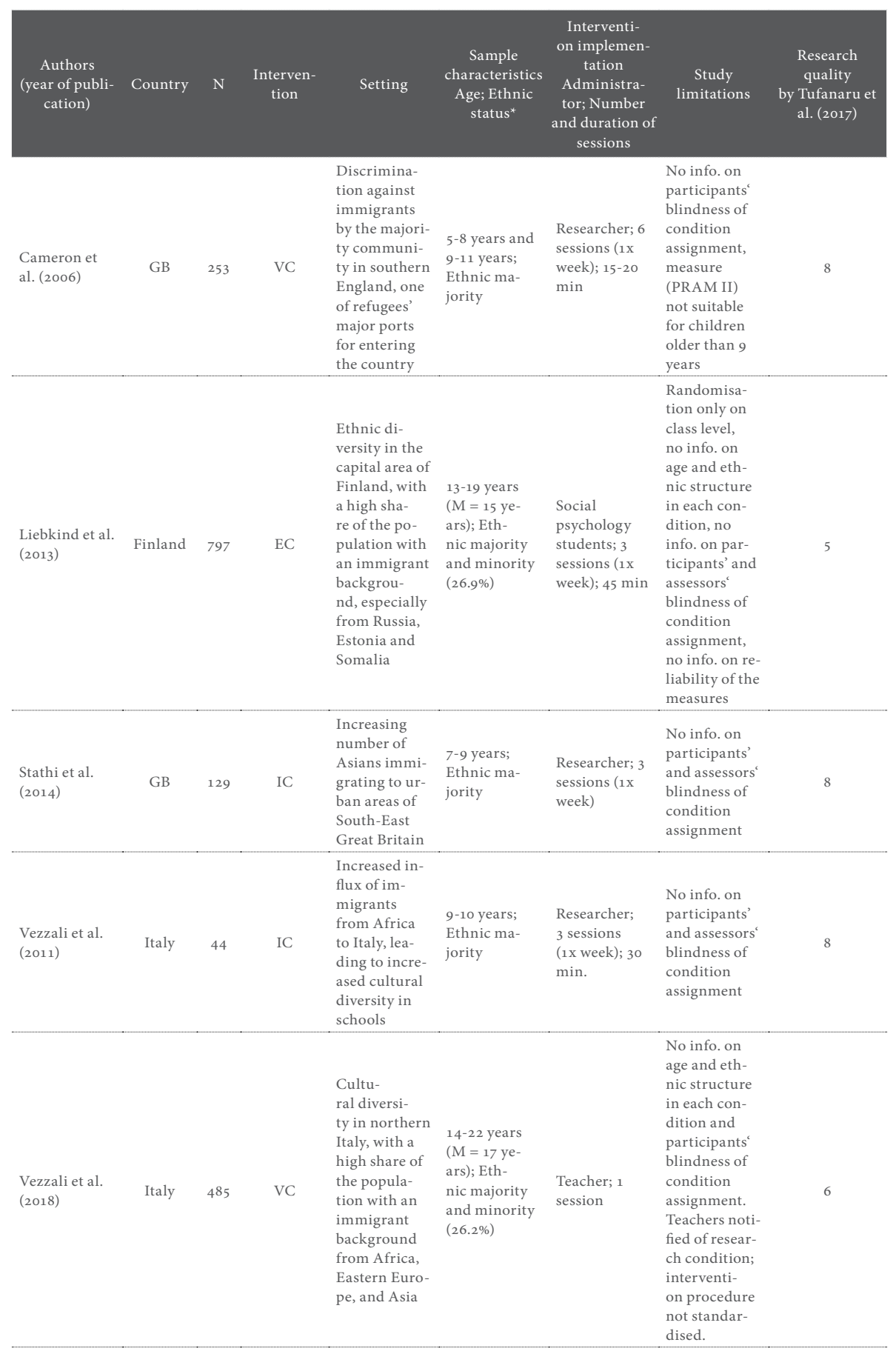




\begin{tabular}{|c|c|c|c|c|c|c|c|c|}
\hline $\begin{array}{l}\text { Authors } \\
\text { (year of publi- } \\
\text { cation) }\end{array}$ & Country & $\mathrm{N}$ & $\begin{array}{l}\text { Interven- } \\
\text { tion }\end{array}$ & Setting & $\begin{array}{c}\text { Sample } \\
\text { characteristics } \\
\text { Age; Ethnic } \\
\text { status* }\end{array}$ & $\begin{array}{c}\text { Interventi- } \\
\text { on implemen- } \\
\text { tation } \\
\text { Administra- } \\
\text { tor; Number } \\
\text { and duration of } \\
\text { sessions }\end{array}$ & $\begin{array}{c}\text { Study } \\
\text { limitations }\end{array}$ & $\begin{array}{c}\text { Research } \\
\text { quality } \\
\text { by Tufanaru et } \\
\text { al. (2017) }\end{array}$ \\
\hline $\begin{array}{l}\text { Vezzali et al. } \\
(2015 a)\end{array}$ & Italy & 200 & $\mathrm{IC}+\mathrm{DC}$ & $\begin{array}{l}\text { Increa- } \\
\text { sing num- } \\
\text { ber of immi- } \\
\text { grants in Italy } \\
\text { during the } \\
\text { height of the } \\
\text { European re- } \\
\text { fugee crisis }\end{array}$ & $\begin{array}{l}8 \text {-10 years; } \\
\text { Ethnic majo- } \\
\text { rity and mi- } \\
\text { nority }(25.5 \%)\end{array}$ & $\begin{array}{l}3 \text { sessions ( } 1 \mathrm{x} \\
\text { week); } 1 \text { hour }\end{array}$ & $\begin{array}{l}\text { No info. on } \\
\text { ethnic stru- } \\
\text { cture in each } \\
\text { condition, } \\
\text { participants', } \\
\text { and assessors' } \\
\text { blindness of } \\
\text { condition } \\
\text { assignment. }\end{array}$ & 7 \\
\hline $\begin{array}{l}\text { Vezzali et al. } \\
(2014)\end{array}$ & Italy & 34 & EC & $\begin{array}{l}\text { Increased cul- } \\
\text { tural diversi- } \\
\text { ty in northern } \\
\text { Italy at the } \\
\text { start of the } \\
\text { European re- } \\
\text { fugee crisis }\end{array}$ & $\begin{array}{l}10 \text { years; Eth- } \\
\text { nic majority }\end{array}$ & $\begin{array}{l}\text { Researcher; } 6 \\
\text { sessions (1x } \\
\text { week) }\end{array}$ & $\begin{array}{l}\text { No info. on } \\
\text { randomisa- } \\
\text { tion, parti- } \\
\text { cipants', and } \\
\text { assessors' } \\
\text { blindness of } \\
\text { condition } \\
\text { assignment. } \\
\text { Low re-test } \\
\text { reliability of } \\
\text { the measure. }\end{array}$ & 6 \\
\hline $\begin{array}{l}\text { Vezzali et al. } \\
\text { (2015b) }\end{array}$ & Italy & 120 & EC & $\begin{array}{l}\text { Increa- } \\
\text { sing num- } \\
\text { ber of immi- } \\
\text { grants in Italy } \\
\text { during the } \\
\text { height of the } \\
\text { European re- } \\
\text { fugee crisis }\end{array}$ & $\begin{array}{l}8 \text { years - } 14 \\
\text { years; Ethnic } \\
\text { majority }\end{array}$ & $\begin{array}{l}\text { Students; } 3 \\
\text { sessions (1x } \\
\text { week); } 2 \text { ho- } \\
\text { urs }\end{array}$ & $\begin{array}{l}\text { Randomisa- } \\
\text { tion only on } \\
\text { class level. } \\
\text { No info on } \\
\text { sample cha- } \\
\text { racteristics } \\
\text { in each con- } \\
\text { dition, parti- } \\
\text { cipants', and } \\
\text { assessors } \\
\text { blindness of } \\
\text { condition } \\
\text { assignment. }\end{array}$ & 6 \\
\hline
\end{tabular}

Note. $\mathrm{GB}=$ Great Britain; $\mathrm{DC}=$ direct contact; $\mathrm{EC}=$ extended contact; $\mathrm{VC}=$ vicarious contact; $\mathrm{IC}=$ imagined contact. * Percentages shown in brackets denote the share of ethnic minority members participating in the study.

\section{References}

Citations marked with an asterisk indicate studies included in the systematic review.

Aboud, F. E., Tredoux, C., Tropp, L. R., Brown, C. S., Niens, U., \& Noor, N. M. (2012). Interventions to reduce prejudice and enhance inclusion and respect for ethnic differences in early childhood: A systematic review. Developmental Review, 32(4), 307-336. https://doi.org/10.1016/j. dr.2012.05.001

Augoustinos, M., \& Rosewarne, D. L. (2001). Stereotype knowledge and prejudice in children. British Journal of Developmental Psychology, 19, 143-156. https://doi.org/10.1348/026151001165912 
Bar-Tal, D. (1996). Development of social categories and stereotypes in early childhood: The case of "the Arab" concept formation, stereotype and attitudes by Jewish

children in Israel. International Journal of Intercultural Relations, 20, 341-370. https://doi.org/10.1016/0147-1767(96)0oo23-5.

Beelmann, A., \& Heinemann, K. S. (2014). Preventing prejudice and improving intergroup attitudes: A meta-analysis of child and adolescent training programs. Journal of Applied Developmental Psychology, 35(1), 10-24. https://doi.org/10.1016/j.appdev.2013.11.002

Benner, A. D., \& Graham, S. (2013). The antecedents and consequences of racial/ethnic discrimination during adolescence: Does the source of discrimination matter? Developmental Psychology, 49(8), 1602-1613. https:// doi.org/10.1037/a0030557

Benner, A. D., \& Kim, S. Y. (2009). Experiences of discrimination among Chinese American adolescents and the consequences for socioemotional and academic development. Developmental Psychology, 45(6), 1682-1694. https://doi.org/10.1037/aoo16119

Berger, R., Benatov, J., Abu-Raiya, H., \& Tadmor, C. T. (2016). Reducing prejudice and promoting positive intergroup attitudes among elementary-school children in the context of the Israeli-Palestinian conflict. Journal of School Psychology, 57, 53-72. https://doi.org/10.1016/j.jsp.2016.04.003

Bilefsky, D. (2021). What drove the Israel-Gaza conflict? Here's what you need to know. The New York Times. https://www.nytimes.com/article/israelgaza-what-we-know.html

Brenick, A., Killen, M., Lee-Kim, J., Fox, N., Leavitt, A., Raviv, S. M., \& AlSmadi, Y. (2010). Social understanding in young Israeli-Jewish, IsraeliPalestinian, Palestinian, and Jordanian children: Moral judgments and stereotypes. Early Education and Development, 21, 886-911. https://doi. org/10.1080/10409280903236598

Brenick, A., Shachner, M. J., Carvalheiro, D., \& Karr, E. (2019). (No) space for prejudice! Varied forms of negative outgroup attitudes and ethnic discrimination and how they develop or can be prevented in the classroom. In H.E. Fitzgerald, D. J. Johnson, D. B. Qin, F. A. Villaruel, \& J. Norder (eds.), Handbook of Children and Prejudice (315-330). Springer Nature Switzerland AG. https://doi.org/10.1007/978-3-030-12228-7

Brewer, M. B. (1999). The psychology of prejudice: Ingroup love or outgroup hate? Journal of Social Issues, 55(3), 429-444. https://doi. org/10.1111/oo22-4537.00126 
Brind, T., Harper, C., \& Moore, K. (2008). Education for migrant, minority and marginalised children in Europe. Open Society Institute. https:// www.opensocietyfoundations.org/uploads/984b2861-e7cc-4d64-aobf7aa6edge3e8d/review_20o80131.pdf

Brown, R., \& Hewstone, H. (2005). An integrative theory of intergroup contact. In M. P. Zanna (eds.), Advances in experimental social psychology, 37 (255-343). Academic Press. https://doi.org/10.1016/Soo65-2601(05)37005-5

Bucik, V. (1997). Osnove psihološkega testiranja. Filozofska fakulteta, Oddelek za psihologijo.

Cameron, L., \& Rutland, A. (2006). Extended contact through story reading in school: Reducing children's prejudice toward the disabled. Journal of Social Issues, 62(3), 469-488. https://doi.org/10.1111/j.1540-4560.2006.00469.x

${ }^{*}$ Cameron, L., Rutland, A., \& Brown, R. (2007). Promoting children's positive intergroup attitudes towards stigmatized groups: Extended contact and multiple classification skills training. International Journal of Behavioral Development, 31(5), 454-466. https://doi.org/10.1177/0165025407081474

${ }^{*}$ Cameron, L., Rutland, A., Brown, R., \& Douch, R. (2006). Changing children's intergroup attitudes toward refugees: Testing different models of Extended contact. Child Development, 77(5), 1208-1219. https://doi. org/10.1111/j.1467-8624.2006.00929.x

Cameron, L., Rutland, A., Turner, R., Holman-Nicolas, R., \& Powell, C. (2011). 'Changing attitudes with a little imagination': Imagined contact effects on young children's intergroup bias. Anales de Psicología, 27(3), 708-717. https://www.redalyc.org/pdf/167/16720048016.pdf

Canefe, N. (2016). Management of irregular migration: Syrians in Turkey as paradigm shifters for forced migration studies. New perspectives on Turkey, 54, 9-32. https://doi.org/10.1017/npt.2016.6

Christ, O., Hewstone, M., Tausch, N., Wagner, U., Voci, A., Hughes, J., \& Cairns, E. (2010). Direct contact as a moderator of extended contact effects: cross-sectional and longitudinal impact on outgroup attitudes, behavioral intentions, and attitude certainty. Personality and Social Psychology Bulletin, 36(12), 1662-1674. https://doi.org/10.1177/0146167210386969

Cocco, V. M., Bisagno, E., Di Bernardo, G. A., Cadamuro, A., Riboldi, S. D., Crapolicchio, E., Trifiletti, E., Stathi, S., \& Vezzali, L. (2021). Comparing story reading and video watching as two distinct forms of vicarious contact: An experimental intervention among elementary school children. British Journal of Social Psychology, 6o, 74-94. https://doi.org/10.1111/ bjso.12404 
Correa-Velez, I., Gifford, S. M., \& McMichael, C. (2015). The persistence of predictors of wellbeing among refugee youth eight years after resettlement in Melbourne, Australia. Social Science \& Medicine, 142, 163-168. https://doi. org/10.1016/j.socscimed.2015.08.017

Dryden-Peterson, S. (2015). Refugee education in countries of first asylum: Breaking open the black box of pre-resettlement experiences. Theory and Research in Education, 14(2), 131-148. https://doi. org/10.1177/1477878515622703

Dustmann, C., \& Preston, I. (2001). Attitudes to Ethnic Minorities, Ethnic Context and Location Decisions. The Economic Journal, 111(470), 353-373. https://doi.org/10.1111/1468-0297.00611

Eurostat. (2017). Asylum statistics in the EU Member States. http://www.ec.europa.eu/eurostat

Falah, G. (1996). Living together apart: Residential segregation in mixed Arab-Jewish cities in Israel. Urban Studies, 33(6), 823-857. https://doi. org/10.1080/00420989650011627

Feddes, A. R., Noack, P., \& Rutland, A. (2009). Direct and Extended Friendship effects on minority and majority children's interethnic attitudes: A longitudinal study. Child Development, 8o(2), 377-39o. https://doi. org/10.1111/j.1467-8624.2009.01266.x

Gibbons, F. X., Etcheverry, P. E., Stock, M. L., Gerrard, M., Weng, C. Y., Kiviniemi, M., \& O’Hara, R. E. (2010). Exploring the link between racial discrimination and substance use: What mediates? What buffers? Journal of Personality and Social Psychology, 99, 785-801. https://doi.org/10.1037/ aoo19880

Glasford, D. E., \& Dovidio, J. F. (2011). E pluribus unum: Dual identity and minority group members' motivation to engage in contact, as well as social change. Journal of Experimental Social Psychology, 47(5), 1021-1024. https://doi.org/10.1016/j.jesp.2011.03.021

Kintz, B. L., Delprato, D. J., Mettee, D. R., Persons, C. E., \& Schappe, R. H. (1965). The experimenter effect. Psychological Bulletin, 63(4), 223-232. https://doi.org/10.1037/hoo21718

Lenhard, W., \& Lenhard, A. (2016). Calculation of effect sizes. https://doi. org/10.13140/RG.2.2.17823.92329

${ }^{\star}$ Liebkind, K., Mähönen, T. A., Solares, E., Solheim, E., \& Jasinskaja-Lahti, I. (2013). Prejudice-reduction in culturally mixed classrooms: The development and assessment of a theory-driven intervention among majority 
and minority youth in Finland. Journal of Community \& Applied Social Psychology, 24(4), 325-339. https://doi.org/10.1002/casp.2168

Miles, E., \& Crisp, R. J. (2013). A meta-analytic test of the imagined contact hypothesis. Group Processes \& Intergroup Relations, 17(1), 3-26. https://doi. org/10.1177/1368430213510573

Moher, D., Liberati, A., Tetzlaff, J., \& Altman, D. G. (2009). Preferred reporting items for systematic reviews and meta-analyses: The PRISMA statement. PLOS Medicine, 6(7). https://doi.org/10.1371/journal.pmed10ooo97

Paluck, E. L., \& Green, D. P. (2009). Prejudice reduction: What works? A review and assessment of research and practice. Annual Review of Psychology, 6o(1), 339-367. https://doi.org/10.1146/annurev.psych.60.110707.163607

Paolini, S., Hewstone, M., \& Cairns, E. (2007). Direct and indirect intergroup friendship effects: Testing the moderating role of the affective and cognitive bases of prejudice. Personality and Social Psychology Bulletin, 33, 1406 - 1420. https://doi.org/10.1177/0146167207304788

Pettigrew, T. F., Christ, O., Wagner, U., \& Stellmacher, J. (2007). Direct and indirect intergroup contact effects on prejudice: A normative interpretation. International Journal of Intercultural Relations, 31(4), 411-425. https://doi. org/10.1016/j.ijintrel.2006.11.003

Pettigrew, T. F., \& Tropp, L. R. (2006). A meta-analytic test of intergroup contact theory. Journal of Personality and Social Psychology, 9o(5), 751-783. https://doi.org/10.1037/0022-3514.90.5.751

Raabe, T., \& Beelmann, A. (2011). Development of ethnic, racial, and national prejudice in childhood and adolescence: A multinational meta-analysis of age differences. Child Development, 82(6), 1715-1737. https://doi. org/10.1111/j.1467-8624.2011.01668.x

Richardson, J. T. (2018). Understanding the under-attainment of ethnic minority students in UK higher education: The known knowns and the known unknowns. In J. Arday, \& H. S. Mirza (eds.), Dismantling Race in Higher Education (87-102). Palgrave Macmillan. https:/doi. org/10.1007/978-3-319-60261-5

Richardson, W. S., Wilson, M. C., Nishikawa, J., \& Hayward, R. S. (1995). The well-built clinical question: a key to evidence-based decisions. ACP Journal Club, 123(3), A12. https://doi.org/10.7326/ACPJC-1995-123-3-A12

Stains, M., \& Vickrey, T. (2017). Fidelity of implementation: An overlooked yet critical construct to establish effectiveness of evidence-based instructional practices. CBE-Life Sciences Education, 16(1), 1-11. https://doi. org/10.1187/cbe.16-03-0113 
*Stathi, S., Cameron, L., Hartley, B., \& Bradford, S. (2014). Imagined contact as a prejudice-reduction intervention in schools: the underlying role of similarity and attitudes. Journal of Applied Social Psychology, 44(8), 536-546. https://doi.org/10.1111/jasp.12245

Steele, C. M., \& Aronson, J. (1995). Stereotype threat and the intellectual test performance of African Americans. Journal of Personality and Social Psychology, 69(5), 797-811. https://doi.org/10.1037/0022-3514.69.5.797

Tobler, A. L., Maldonado-Molina, M. M., Staras, S. A., O’Mara, R. J., Livingston, M. D., \& Komro, K. A. (2013). Perceived racial/ ethnic discrimination, problem behaviors, and mental health among minority urban youth. Ethnicity \& Health, 18, 337-349. https://doi.org/10.1080/13557858.2012.730 609

Tropp, L. R., \& Ramiah, A. A. (2017). Contact strategies for improving intergroup relations among youth. The Wiley Handbook of Group Processes in Children and Adolescents, 353-372. https://doi.org/10.1002/9781118773123. ch17

Tufanaru C., Munn Z., Aromataris E., Campbell J., \& Hopp L. (2017). Chapter 3: Systematic reviews of effectiveness. In E. Aromataris in Z. Munn (eds.), Joanna Briggs Institute Reviewer's Manual (4-9). The Joanna Briggs Institute. https://reviewersmanual.joannabriggs.org/

Turner, R. N., Hewstone, M., Voci, A., Paolini, S., \& Christ, O. (2007). Reducing prejudice via direct and extended cross-group friendship. European Review of Social Psychology, 18(1), 212-255. https://doi. org/10.1080/10463280701680297

Ülger, Z., Dette-Hagenmeyer, D. E., Reichle, B., \& Gaertner, S. L. (2018). Improving outgroup attitudes in schools: A meta-analytic review. Journal of School Psychology, 67, 88-103. https://doi.org/10.1016/j.jsp.2017.10.002

UNHCR. (2018). Global trends: forced displacement in 2017. https://www.unhcr.org/statistics/unhcrstats/5b27be547/unhcr-global-trends-2017.html

*Vezzali, L., Capozza, D., Giovannini, D., \& Stathi, S. (2011). Improving implicit and explicit intergroup attitudes using imagined contact: An experimental intervention with elementary school children. Group Processes \& Intergroup Relations, 15(2), 203-212. https://doi. org/10.1177/1368430211424920

${ }^{\star}$ Vezzali, L., Di Bernardo, G. A., Stathi, S., Visintin, E. P., \& Hewstone, M. (2018). Using intercultural videos of direct contact to implement vicarious contact: A school-based intervention that improves intergroup attitudes. 
Group Processes \& Intergroup Relations, 22(7), 1059-1076. https://doi. org/10.1177/1368430218809885

*Vezzali, L., Stathi, S., Crisp, R. J., \& Capozza, D. (2015a). Comparing direct and imagined intergroup contact among children: Effects on outgroup stereotypes and helping intentions. International Journal of Intercultural Relations, 49, 46-53. https://doi.org/10.1016/j.ijintrel.2015.06.0o9

*Vezzali, L., Stathi, S., Giovannini, D., Capozza, D., \& Trifiletti, E. (2014). The greatest magic of Harry Potter: Reducing prejudice. Journal of Applied Social Psychology, 45(2), 105-121. https://doi.org/10.1111/jasp.12279

*Vezzali, L., Stathi, S., Giovannini, D., Capozza, D., \& Visintin, E. P. (2015b). "And the best essay is...": Extended contact and cross-group friendships at school. British Journal of Social Psychology, 54(4), 601-615. https://doi. org/10.1111/bjso.12110

Wright, S. C., Aron, A., Mclaughlin-Volpe, T., \& Ropp, S. A. (1997). The extended contact effect: Knowledge of cross-group friendships and prejudice. Journal of Personality and Social Psychology, 73(1), 73-90. https://doi. org/10.1037/0022-3514.73.1.73 